\title{
Opportunity Rover's image analysis: Microbialites on Mars?
}

\section{Giorgio Bianciardi*, **}

Dpt. Medical Biotechnologies, University of Siena, Siena, Italy

\section{Vincenzo Rizzo**}

National Research Council - retired -, Via Repaci 22, Rende, Cosenza, Italy

\section{Nicola Cantasano}

National Research Council, Institute for Agricultural and Forest Systems in the Mediterranean, Rende Research Unit, Cosenza, Italy

\begin{abstract}
The Mars Exploration Rover Opportunity investigated plains at Meridiani Planum, where laminated sedimentary rocks are present. The Opportunity rover's Athena morphological investigation showed microstructures organized in intertwined filaments of microspherules: a texture we have also found on samples of terrestrial (biogenic) stromatolites and other microbialites. We performed a quantitative image analysis to compare images $(n=45)$ of microbialites with the images $(n=30)$ photographed by the rover (corresponding, approximately, to 25,000/15,000 microstructures). Contours were extracted and morphometric indexes were obtained: geometric and algorithmic complexities, entropy, tortuosity, minimum and maximum diameters. Terrestrial and Martian textures present a multifractal aspect. Mean values and confidence intervals from the Martian images overlapped perfectly with those from the terrestrial samples. The probability of this occurring by chance is $1 / 2^{8}$, less than $\mathrm{p}<0.004$. Terrestrial abiogenic pseudostromatolites showed a simple fractal structure and different morphometric values from those of the terrestrial biogenic stromatolite images or Martian images with a less ordered texture ( $p<0.001)$. Our work shows the presumptive evidence of microbialites in the Martian outcroppings: i.e., the presence of unicellular life on the ancient Mars.
\end{abstract}

Key words: Mars Exploration Rovers, microbialites, fractal analysis, life on Mars.

\section{Introduction}

The Mars Exploration Rover "Opportunity" investigated the landing site in Eagle crater and the nearby plains within Meridiani Planum where flat-lying sedimentary rocks are present. These rocks are finely laminated, are rich in sulfur, and contain abundant sulfate salts. Small-scale crosslamination provided evidence for deposition in shallow flowing liquid water [1].

Although not without controversy [2], microbialites, such as stromatolites, are often interpreted as the oldest evidence of life on Earth [3-6]: an interpretation predicated on the assumption that these rocks are formed by microbial mats trapping, binding and/or precipitating minerals.

As regards microstructures in stromalites, Walter highlighted a great variety of microfabrics, reporting ribboned, striated and lumpy types, and showing that these microfabrics are due to micro-laminated sequence that could be distinct in diffuse or massive [7]. In recent view, stromatolites have been defined as "macroscopically layered authigenic microbial sediments", namely organosedimentary rocks. The term thrombolites [8] was given for not-layered-generally clotted
This is an Open Access article distributed under the terms of the Creative Commons Attribution Non-Commercial License (http://creativecommons.org/licenses/by$\mathrm{nc} / 3.0 /$ which permits unrestricted non-commercial use, distribution, and reproduction in any medium, provided the original work is properly cited. (cc) Corresponding author: giorgio.bianciardi@unisi.it
** These authors equally contributed to the study. 
similar rocks, while microbialites is a more general term given for rocks of microbial origin. A further distinction in dendrolite, thrombolite, stromatolite and leolite, was suggested by considering the internal mesostructures [9]. A particular case, with some doubt, given by the occurrence of similar precipitates in an abiogenic crust, identified in both Precambrian and Phanerozoic sediments and made by interlayered or mixed biogenic and abiogenic materials (Hybrid Crust, [10]), was evidenced by several Authors $[11,2]$. Given the wide presence and the relevant role of cyanobacteria in organosedimentary rock formations, all these varieties could be seen as structural differences of the classical defined stromatolites/microbialites.

Biogenicity, as suggested by Riding [12], is structurally characterized by the occurrence of fine-grained microfabric, clotted, peloidal or filamentous patterns in micritic and irregular layering. Occurrence of intertwined filaments has also been reported in a recent study on gypsum stromatolite [13]. The widespread occurrence of peloidal structures is generally attributed to bacterial activity, particularly in Precambrian and within salt/sulphate rich water environment [14]. Stromatolites are also a frequently named target of life-detection missions on Mars [15-20].

We have previously observed that images of Martian outcroppings (selected frames from images obtained by Opportunity and Spirit rovers), present macro-, meso- and microstructures that resemble terrestrial stromatolites/ microbialites (Fig. 1) [21,22].

In a work by Wagstaff and Corsetti, a complexity comparison between the samples of terrestrial stromatolites
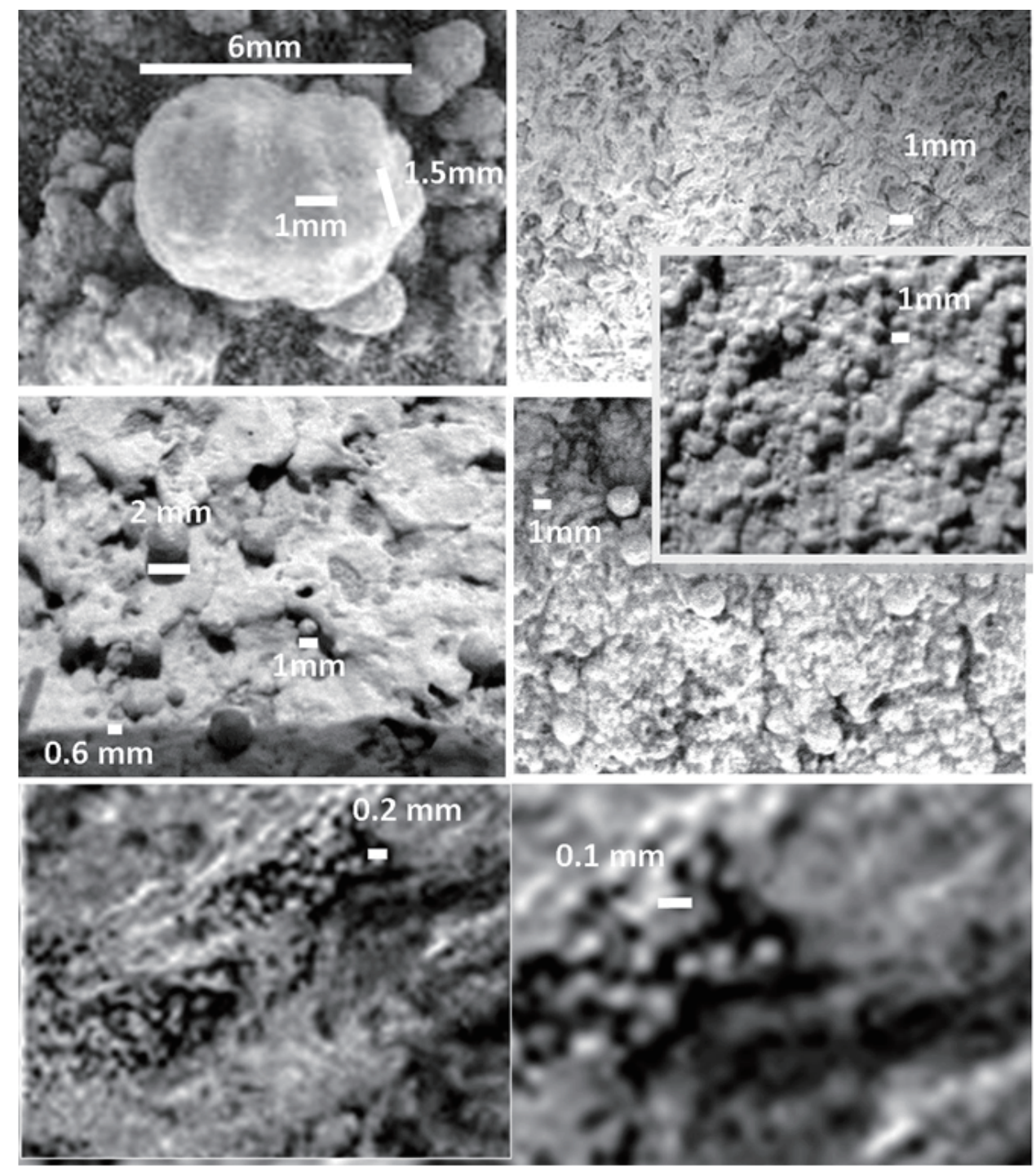

Fig. 1. Mars: Mi rover images: A selection of Ml rover images showing occurrence of spherules of various dimensions, from macroscopic (top) to microscopic (below) levels. Microspherules are assembled in filament arrays (below). 
(biogenic and abiogenic pseudostromatolites) and four Martian samples photographed by the rover Opportunity found no identification with terrestrial, biogenic, stromatolites [23].

In order to assess the real occurrence, or not, of stromatolites/microbialites on Mars, we have carried out an extensive visual investigation of sedimentary microstructures and a quantitative, objective, image analysis to compare, at the same scale of observation, images of terrestrial, biogenic, stromatolites and other microbialites, fossils and living ones (forty-five images) with a selected set of microscopic images (MI Athena, [24]) obtained by the rover Opportunity on Mars (thirty images).

\section{Materials and methods}

\subsection{Samples}

As regards Martian sediments, this study undertakes a systematic analysis of black and white Microscopic Images (MI) obtained by Athena (Fig. 1), a camera mounted on the NASA Mars Exploration Rovers (MER) "Opportunity" and "Spirit" [24]. The field of view of Athena is $1024^{*} 1024$ pixels in size and its optics provides a square frame of $32 \mathrm{~mm}$ of-

Table 1. Sampled images: Martian samples photographed by Opportunity and terrestrial (biogenic) stromatolites or other microbialites selected by WEB sites or photographed by us at the Regional Museum of Natural Sciences, Turin or provided by E.M. Farias (Conicet, Argentina).

\begin{tabular}{|c|c|c|c|c|c|c|c|}
\hline \multicolumn{4}{|c|}{ MARS (Rover Microscopic Imagery selection) } & \multicolumn{4}{|c|}{ EARTH (fossil and living microbialites) } \\
\hline 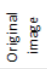 & 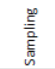 & SOL & Source & 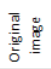 & 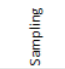 & Stromatolites & Source \\
\hline 1 & 1 & SOL 50 & \begin{tabular}{|c|} 
http://marsrover.nasa.gov/gallery/a \\
II/1/m/050/1M132624786EFFo602P \\
2956M2M1.JPG \\
\end{tabular} & 1 & 1_5 & $\begin{array}{c}\text { Recent stromat. (a), Lagoa } \\
\text { Salgada, Brazil (Srivastava, } \\
\text { 1999; fig. 5) }\end{array}$ & $\frac{\text { http: } / / \text { sigep.cprm.gov.br/sitio041/si }}{\underline{\text { tio041.htm }}}$ \\
\hline 2 & 2 & SOL 214 & $\begin{array}{l}\text { http: //marsrover.nasa.gov/gallery/a } \\
11 / 1 / \mathrm{m} / 214 / 1 \mathrm{M} 147182851 \mathrm{EFF} 35 \mathrm{BG} P \\
\text { 2957M2M1.JPG }\end{array}$ & 2 & $6 \_8$ & $\begin{array}{l}\text { Living microbialite, La Brava, } \\
\text { Salar de Atacama, Chile }\end{array}$ & $\begin{array}{l}\text { provided by EM Farias, Conseio } \\
\text { Nacional de Investigaciones } \\
\text { Centificas Y Técnicas (CONICE) }\end{array}$ \\
\hline 3 & 3 & SOL 217 & 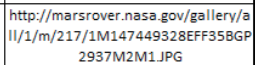 & 3 & 9_12 & $\begin{array}{l}\text { Proterozoic columnar } \\
\text { stromatolite, Mauritania } \\
\text { (Borque collection) }\end{array}$ & $\begin{array}{l}\text { http://wwww2.ggl.ulaval.ca/personel } \\
\text { Lborque/54/stromatolites.anciens }\end{array}$ \\
\hline 4 & 4 & SOL 217 & \begin{tabular}{|c|} 
http: //marsrover.nasa.gov/gallery/a \\
11/1/m/217/1M147449390EFF35BGP \\
2937M2M1.JPG \\
\end{tabular} & 4 & 13 & $\begin{array}{l}\begin{array}{l}\text { Proterozoic stromatolite, South } \\
\text { Africa } \\
\text { (Schopf, } \\
2006 ; \text {; fig 1, c) }\end{array} \\
\end{array}$ & $\begin{array}{c}\text { www.kevobs.be/fr/ebonino/html/str } \\
\text { omatoliti.html }\end{array}$ \\
\hline 5 & 5 & SOL 258 & \begin{tabular}{|c|} 
http://marsrover.nasa.gov/gallery/a \\
II/1/m/217/1M151088791EFF36CLP \\
2977M2M1.JPG
\end{tabular} & 5 & 14 & $\begin{array}{c}\text { Devonian columnar } \\
\text { stromatolite, Australia (Borque } \\
\text { coll.) }\end{array}$ & $\begin{array}{l}\text { http://wwww2.gpl.ulaval.ca/personel } \\
\text { borque/s4/stromatolites.anciens } \\
\end{array}$ \\
\hline 6 & $6 \_10$ & SOL258 & $\begin{array}{l}\text { http://marsrover.nasa.gov/gallery/a } \\
\text { II/1/m/217/1M151092408EFF36CLP } \\
\text { 2977M2M1.JPG }\end{array}$ & 6 & 15 & $\begin{array}{l}\text { Stromatolite shots on Earth by } \\
\text { Athena }\end{array}$ & http://marsrover.nasa.gov \\
\hline 7 & 11 & SOL 258 & \begin{tabular}{|c|} 
http://marsrover.nasa.gov/gallery/a \\
II/1/m/258/1M151092715EFF36CLP \\
2956M2M1.JPG \\
\end{tabular} & 7 & 16 & \begin{tabular}{|c}
$\begin{array}{c}\text { Proterozoic stromat, Collenia } \\
\text { type, Michigan, USA (University } \\
\text { museum) }\end{array}$ \\
\end{tabular} & \begin{tabular}{|l|} 
http://wwww.fossilmuseum.net/Fossi \\
$\underline{\text { IGalleries/Stromatolites/str54 }}$ \\
\end{tabular} \\
\hline 8 & $12 \_13$ & SOL 354 & \begin{tabular}{|c|} 
http://marsrover.nasa.gov/gallery/a \\
11/2/m/354/2M157793043EFFA269P \\
2959M2M1JPG \\
\end{tabular} & 8 & $\underline{17}$ & $\begin{array}{c}\text { Silurian stromat,, Gotland, } \\
\text { Sweden (Nose et al., 2006; fig } \\
\text { 12) } \\
\end{array}$ & $\frac{\text { http://www.sciencedirect.com/scien }}{\text { ce/article }}$ \\
\hline 9 & 14 & SOL 354 & $\begin{array}{c}\text { http: }: / \text { marsrover.nasa.gov/gallery/a } \\
\text { 11/2/m/354/2M157793588EFFA269P } \\
\text { 2977M2M1 }\end{array}$ & 9 & 18 & $\begin{array}{l}\text { Proterozoic stromat, } \\
\text { Earaheedia type, Wiluna, } \\
\text { Austr. (Bonino coll.). }\end{array}$ & $\begin{array}{c}\frac{\text { wwww.kevobs. be } / \mathrm{fr} / \text { ebonino/html/str }}{\text { omatoliti.html }} \\
\end{array}$ \\
\hline 10 & $15 \_16$ & SOL 598 & \begin{tabular}{|c|} 
httpmarsrover.nasa.gov/gallery/all/ \\
1/m/598/1M181273197EFF6200P29 \\
36M2M1.JPG
\end{tabular} & 10 & 19 & $\begin{array}{l}\text { Proterozoic stromat, BIF type, } \\
\text { Pillbara, Austr. (Bonino coll.) }\end{array}$ & $\begin{array}{c}\text { www.keyobs.be/fr/ebonino/html/str } \\
\text { omatoliti.html }\end{array}$ \\
\hline 11 & 17_18 & SOL 684 & $\begin{array}{c}\text { http: ://marsrover.nasa.gov/gallery/a } \\
\text { 11/1/m/684/1M188905974EFF64KCP } \\
\text { 2957M2M1.JPG }\end{array}$ & 11 & 20 & \begin{tabular}{|c|} 
Paleoproterozoic stromat, \\
Cochabamba, Bolivia (Bonino \\
coll.).
\end{tabular} & $\begin{array}{c}\text { www.keyobs.be/fr/ebonino/html/str } \\
\text { omatoliti.html }\end{array}$ \\
\hline 12 & 19 & SOL 684 & \begin{tabular}{|c|} 
http://marsrover.nasa.gov/gallery/a \\
II/1/m/684/1M188905467EFF64KCP \\
2936M2M1.JPG \\
\end{tabular} & 12 & 21 & $\begin{array}{c}\text { Paleoproterozoic stromat,, } \\
\text { Collenia type, Minnesota, USA } \\
\text { (Bonino coll.) } \\
\end{array}$ & $\begin{array}{c}\text { www.keyobs.be/fr/ebonino/html/str } \\
\text { omatoliti.html }\end{array}$ \\
\hline 13 & 20 & SOL 791 & \begin{tabular}{|c|} 
http://marsrover.nasa.gov/gallery/a \\
II/1/m/791/1M198405741EFF6809 \\
P2956M2M1.JPG
\end{tabular} & 13 & 22 & $\begin{array}{c}\begin{array}{c}\text { Paleoproterozoic stromat., } \\
\text { Cochabamba, Bolivia (Bonino } \\
\text { coll.). }\end{array} \\
\end{array}$ & $\begin{array}{c}\text { www.keyobs.be/fr/ebonino/html/str } \\
\text { omatoliti.html }\end{array}$ \\
\hline 14 & 21 & SOL 1045 & \begin{tabular}{|c|} 
http://marsrover.nasa.gov/gallery/a \\
II/1/m/1045/1M220953786EFF7800 \\
P2936M2M1.JPG \\
\end{tabular} & 14 & 23 & $\begin{array}{c}\text { Cretaceous stromat, } \\
\text { Pocalithus type, Potosi, Bolivia. }\end{array}$ & $\begin{array}{c}\text { http://www.lowestone.com/acatalo } \\
\mathrm{g} / \text { /Fossils-for-sale.html }\end{array}$ \\
\hline 15 & 22 & SOL 1178 & \begin{tabular}{|c|} 
http://marsrover.nasa.gov/gallery/a \\
II/1/m/1178/1M232762128EFF82_ \\
P2950M2M1.JPG
\end{tabular} & 15 & $24 \_26$ & $\begin{array}{l}\text { Middle Devonian stromat., } \\
\text { Orcadian Lake, Scotland } \\
\text { (University Museum) }\end{array}$ & $\begin{array}{c}\text { http: } / / \text { www.landforms.eu/orknev/Fo } \\
\underline{s 5 i l s / \text { stromatolite.htm }}\end{array}$ \\
\hline 16 & 23 & SOL 1320 & \begin{tabular}{|c|} 
http://marsrover.nasa.gov/gallery/a \\
II/1/m/1320/1M245369507EFF8700 \\
P2956M2M1.JPG \\
\end{tabular} & 16 & 27 & $\begin{array}{l}\text { Archean stromat., Wyoming, } \\
\text { USA (EDCOPE) }\end{array}$ & $\begin{array}{c}\text { httpp://wwww.fossilmall.com/EDCOPE } \\
\text { Enterprises/stromatolite }\end{array}$ \\
\hline 17 & 24 & SOL 1332 & \begin{tabular}{|c|} 
http://marsrover.nasa.gov/gallery/a \\
II/1/m/1332/1M246430353EFF8788 \\
P2956M2M1.JPG \\
\end{tabular} & 17 & 28 _ 30 & $\begin{array}{c}\text { Precambrian stromat., BIF type, } \\
\text { Minnesota, USA. (James St. John } \\
\text { coll.) }\end{array}$ & $\begin{array}{l}\text { http://www.newark.osu.edu/faculty } \\
\text { staff/personal/istiohn/Documents }\end{array}$ \\
\hline 18 & 25 & SOL 1747 & \begin{tabular}{|c|} 
http://marsrover.nasa.gov/gallery/a \\
II/1/m/1747/1M283283112EFF9482 \\
P2996M2M1.JPG \\
\end{tabular} & 18 & 31_35 & $\begin{array}{c}\text { Precambrian stromat., } \\
\text { Chocabamba,Bolivia. Sample } \\
\text { R2162. } \\
\end{array}$ & \begin{tabular}{|c|}
$\begin{array}{c}\text { Photos shot at Regional Museum of } \\
\text { Natural Sciences, Turin. }\end{array}$ \\
\end{tabular} \\
\hline 19 & 26 & SOL 1833 & \begin{tabular}{|c|} 
http://marsrover.nasa.gov/gallery/a \\
11/1/m/1833/1M290915181EFF99E0 \\
P2956M2M1.JPG \\
\end{tabular} & 19 & $36-40$ & $\begin{array}{c}\text { Precambrian stromat, } \\
\text { dolomitic, South Africa. Sample } \\
3713 . \\
\end{array}$ & $\begin{array}{c}\text { Photos shot at Regional Museum of } \\
\text { Natural Sciences, Turin. }\end{array}$ \\
\hline 20 & 27 & SOL 1886 & \begin{tabular}{|c|} 
http://marsrover.nasa.gov/gallery/a \\
II/1/m/1886/1M295611857EFFAO_ \\
P2976M2M1.JPG
\end{tabular} & 20 & 41_45 & $\begin{array}{l}\text { Middle Cambrian Stromat,, } \\
\text { Qiniiamiao Formation, } \\
\text { Xinshan, China. Sample } \\
\text { GEO5216. }\end{array}$ & $\begin{array}{l}\text { Photos shot at Regional Museum of } \\
\text { Natural Sciences, Turin. }\end{array}$ \\
\hline 21 & 28 & SOL 2695 & $\begin{array}{l}\text { http: ://marsrover.nasa.gov/gallery/a } \\
\text { II/1/m/2695/1M367438666EFFBML } \\
\text { VP2956M2M1.JPG }\end{array}$ & & & & \\
\hline 22 & 29 & SOL 2829 & \begin{tabular}{|c|} 
http: //marsrover.nasa.gov/gallery/a \\
11/1/m/2829/1M379328948EFFBR43 \\
P2905M2M1.JPG \\
\end{tabular} & & & & \\
\hline 23 & 30 & $\begin{array}{l}\text { SOL } \\
2974\end{array}$ & \begin{tabular}{|c|} 
http://marsrover.nasa.gov/gallery/a \\
II/1/m/2974/1M392205583EFFBRAA \\
P2955M2M3.JPG
\end{tabular} & & & & \\
\hline
\end{tabular}


field sampling at the working distance of about $63 \mathrm{~mm}$ from the front of the lens barrel to the object plane, consequently having a resolution of about 30 micrometers [24]. In particular, twenty-three selected MI images obtained by the rover Opportunity have been chosen (Table 1, column 4) and thirty samplings have been obtained (amplified cuttings of the original images; Table 1, column 2), approximately corresponding to the presence of 15,000 microspherule/ intertwined filaments.

These cuttings, having dimensions of about $1 / 4$ of the original images (8-12 mm), were subjected to a slight contrast increase (Microsoft Publisher software) for an optimal vision of the microstructures. The thirty studied cuttings were related to polished surfaces by MER's Rock Abrasion Tool (RAT) or to exposed surfaces of the Martian outcroppings.

As regards terrestrial microbialites, fossil stromatolites and other (living) microbialites unambiguously determined as biogenic, twenty quoted images (images released by the WEB, including one sample photographed by Athena on Earth, samples photographed by us at the Regional Museum of Natural Sciences, Turin, and living microbialites from E.M. Farias collection) were used (Table 1, column 8). Fortyfive samplings ( 9 samplings from recent/living microbialites, 15 samplings from the three stromatolites photographed by us, the others from the WEB) were obtained (corresponding to approximately 25,000 microspherules/ filaments) (Table 1, column 6). They have been acquired, magnified, and processed in order to obtain the same $( \pm 10 \%)$ magnification, resolution, and acutance of the Athena imagery. They were analyzed using the same procedures of the Martian images. Previously, photos of stromatolites from museum samples (University of Calabria, Italy) have been obtained to test image samplings at various conditions in order to standardize the procedures. The color images were transformed in grey shades (Fig. 2).

Ten images from samples of terrestrial abiogenic pseudostromatolites (speleothems: alabaster, amethyst geode, chalcedony, malachite, see Fig. 10) and of a synthetic pseudostromatolite (sample from McLoughlin et al., 2008, see Fig. 9) were processed and analyzed using the same
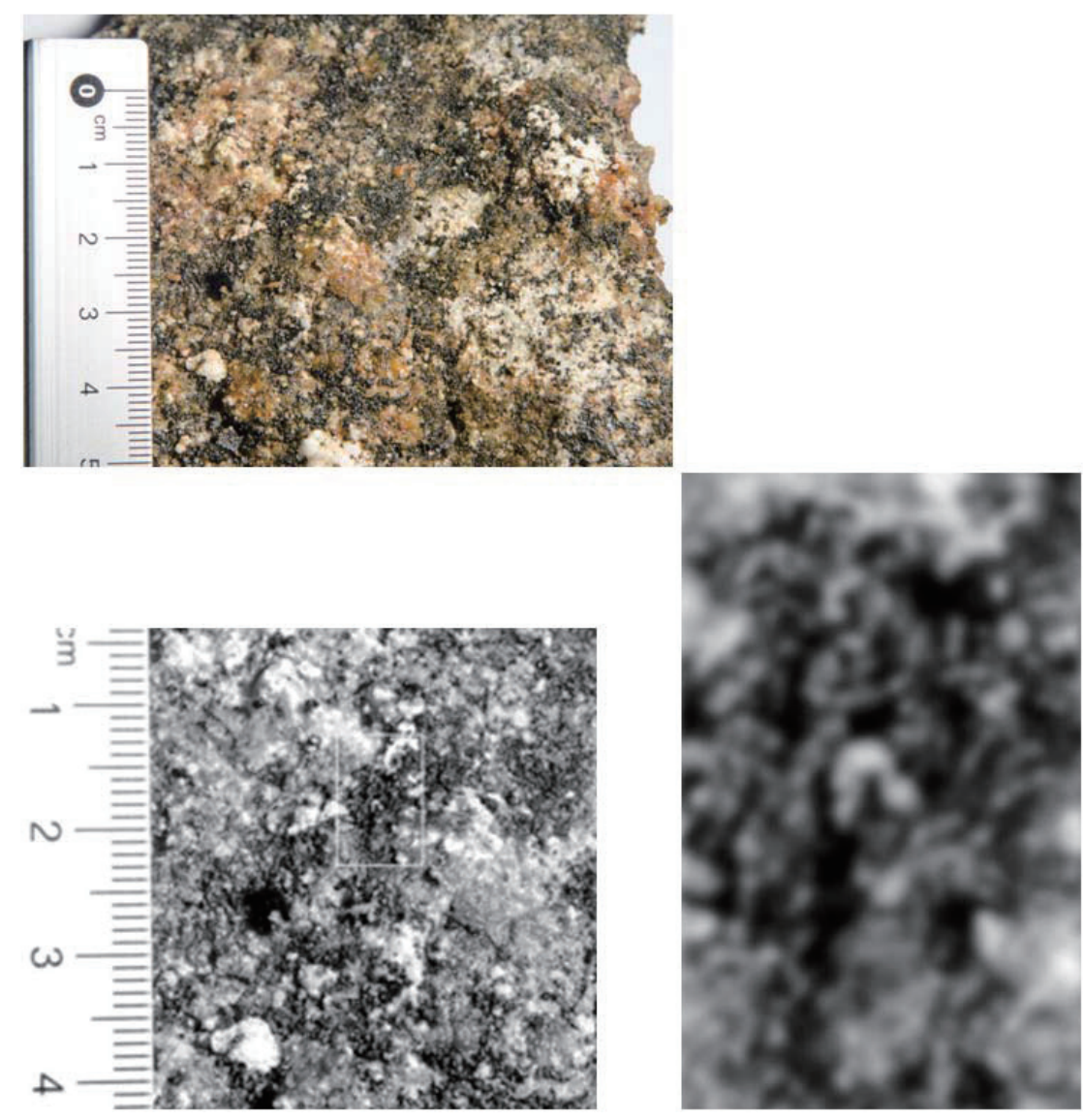

Fig. 2. Earth: living stromatolites: A colour image of a living microbialite (top), transformed in grey shades (below, left), a 1-cm-length portion is enlarged and defocused (gaussian filter) (below, right), in order to obtain the same ( $\pm 10 \%)$ magnification, resolution and acutance of the Athena Imagery system (Opportunity Rover, Mars). Carbonatic microbialite, made by extremophiles, from thalassic wetlands (La Brava, Salar de Atacama, Chile). Sample provided by E.M. Farias (CONICET, Argentina). 
procedures as above.

\subsection{Image analysis}

The contours present in the terrestrial and Martian images (biogenic microbialites and selected images shot by Opportunity) were automatically extracted from the images and converted to single pixel outlines by a canny-edge filter (Digital Image Magnifier software by Strikos Nikolaos: http://www.softoxi.com/digital-image-magnifier.html), (fixed sigma and low threshold values, equals to 0.9 and 12 , respectively) (Fig. 3).

The obtained textures were characterized by analyzing their geometrical complexity, Entropy (Information Dimension), algorithmic complexity (L-Z, randomness), and tortuosity (Dmin). Minimum and maximum diameters of the microspherules were also measured.

\subsubsection{Geometric Complexity, D0}

To evaluate the geometric complexity of the patterns, the local fractal dimension was measured using the boxcounting algorithm (scales: $200-10$ pixels $=2 \mathrm{~mm}-0.1 \mathrm{~mm}$ and 10-5 pixels $=0.1 \mathrm{~mm}-0.05 \mathrm{~mm}$; see Fig. 4). Briefly, each image was covered by a net of $\mathrm{L}$ square boxes, and the number of boxes containing any part of the outline $\mathrm{Nb}(\mathrm{L})$ was counted. The slope of the $\log$ - $\log$ plot of $\mathrm{Nb}(\mathrm{L})$ vs. $1 / \mathrm{L}$ represented the fractal dimension of the distribution (Fig. 4, [25]. The existence of log-log straight lines $(\mathrm{p}<0.001)$ justified the use of the fractal analysis, applied here as a tool to obtain the morphometric indexes. The method was validated by measuring computer-generated Euclidean and fractal shapes of known fractal dimensions (Circumference $=-0.7 \%$;
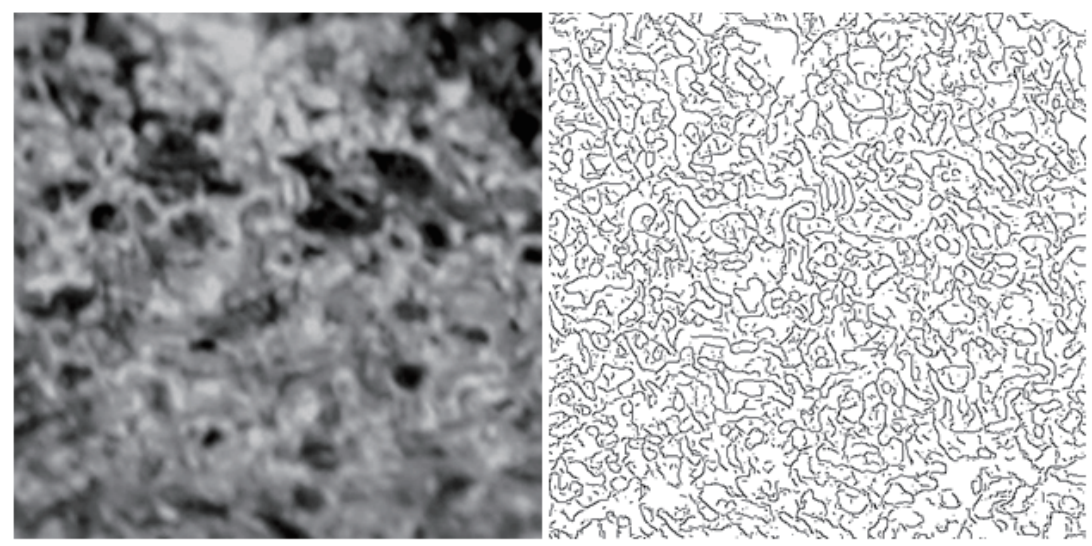

EARTH $1 \mathrm{~mm}$
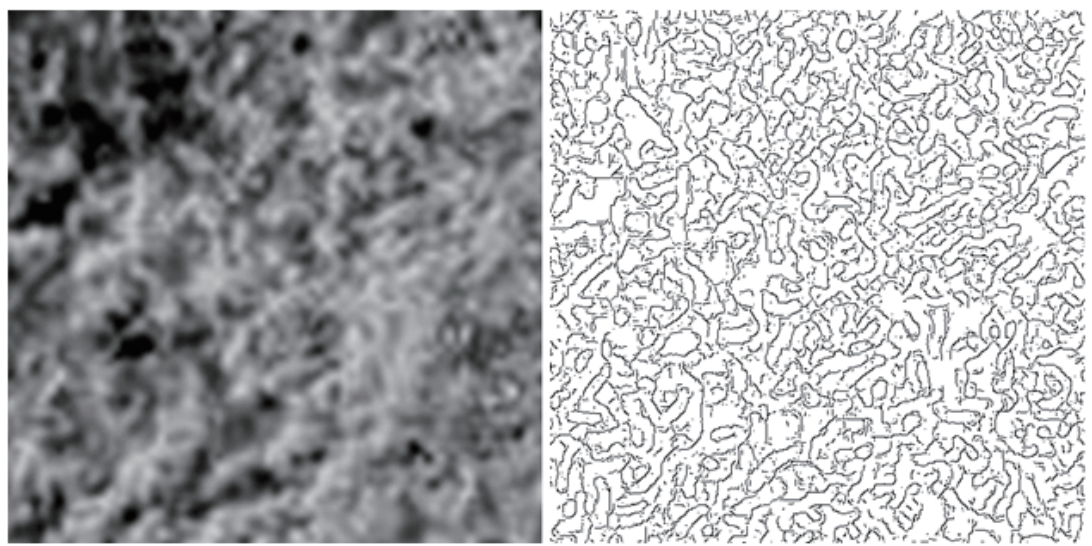

MARS $\quad 1 \mathrm{~mm}$

Fig. 3. Earth vs. Mars: Terrestrial sample of a microbialite (stromatolite, sample 28, Table 1, top, left) and its automatically extracted contours (top, right); a Martian sample photographed by Opportunity Rover (sample 17, Table 1, below, left) and its automatically extracted contours (below, right). Magnification is the same $( \pm 10 \%)$. 
Square $=+0.4 \%$; Triadic Koch island $=-0.9 \%$; Sierpinski's Triangle $=-1.5 \%)$.

\subsubsection{Entropy (Information Dimension, D1)}

To evaluate the information present in the patterns, the information dimension (entropy, D1), a robust estimate from a finite amount of data that gives the probability of finding a point in the image, was calculated. The set was covered with boxes of linear size, $d$, from 200 to 10 pixels and from 10 to 5 pixels as above, keeping track of the mass, mi (the amount of pixels) in each box, and the information entropy I(d) from the summation of the number of points in the i-th box divided by the total number of points in the set multiplied for its logarithm [26] was measured. The slope of the log-log plot of Information entropy vs. 1/box side length represented the information dimension of the distribution. The method was validated by measuring computer generated Euclidean and fractal shapes of known information dimensions. The existence of log-log straight lines $(\mathrm{p}<0.001)$ justified the use of the fractal analysis, applied here as a tool to obtain the morphometric indexes.

\subsubsection{Algorithmic complexity ("randomness", L-Z)}

To determine the algorithmic complexity ("randomness") of the patterns, relative Lempel-Ziv, L-Z, values were calculated according to the Kaspar and Schuster algorithm [27] using the Chaos Data Analyzer version 2.1 software package (CDA Pro, Academic Software Library, North Carolina State University, USA). Briefly, patterns of the original image were transformed into 16,732 points containing one dimensional vector, where each datum point was converted into a single binary digit according to whether the design is touched $(=1)$ or not $(=0)$. Relative $\mathrm{L}-\mathrm{Z}$ value is close to 0 for a deterministic equation, close to 1 for totally destructured random phenomena.

\subsubsection{Tortuosity (Dmin)}

Tortuosity, or the fractal dimension of the minimum path, Dmin, was computed for each cluster present in the image from the power law Ic $=\mathrm{r}^{\mathrm{Dmin}}$, where Dmin is the exponent that governs the dependence of the minimum path length between two points (Ic) on the Pythagorean distance (r) measured between them. To obtain Dmin, the maximum diameter and the half perimeter of the microstructures present in the textures were measured using an automated procedure (Image Pro Plus software, Media Cybernetics, USA). For each image, 100-500 microstructures were measured. The slope of the log-log plot (maximum diameter vs. perimeter) represented Dmin. The existence of a log-log straight line $(\mathrm{p}<0.001)$ justified the use of the fractal analysis
EARTH

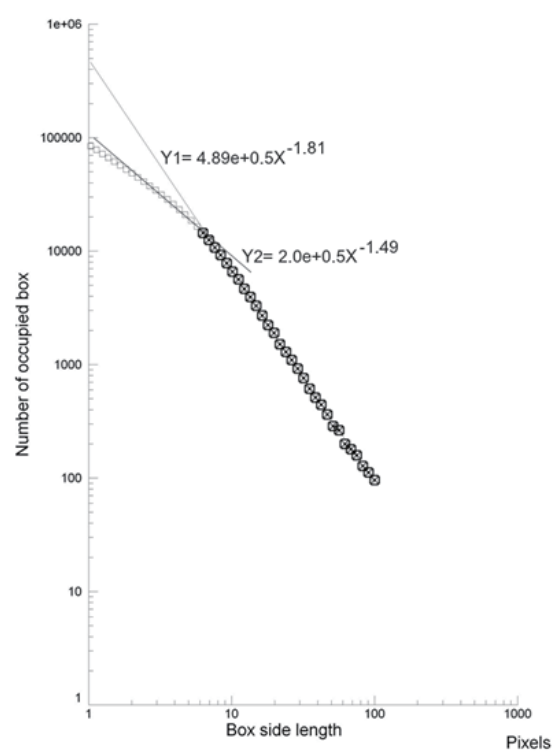

MARS

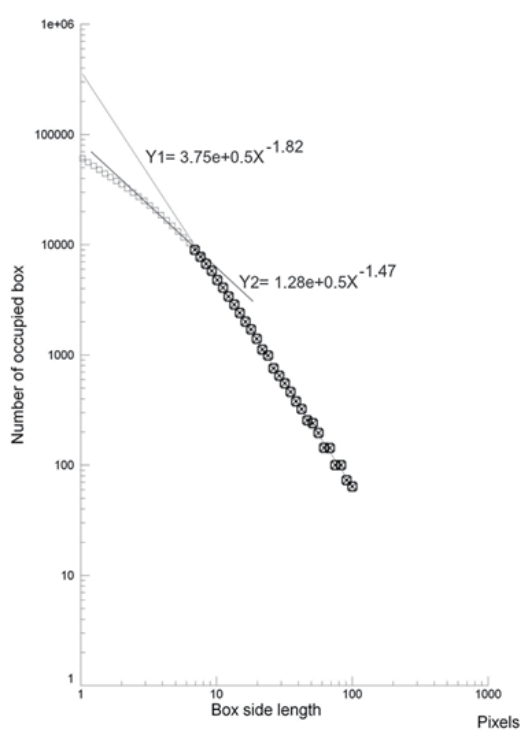

Fig. 4. Earth vs. Mars: Left, log-log plot of a terrestrial sample of a biogenic stromatolite (sample 28, Table 1: the same of Fig. 3), and of a Martian sample photographed by the Opportunity Rover, right (sample 17, Table 1: the same of Fig. 3). Both the samples are multifractals, as evidenced by the presence of two straight lines with different slopes. Please, note the remarkable similarity of the two log-log plots (Earth/ Mars) and of its critical exponents (geometric complexities or local fractal dimensions by box-counting). Magnification is the same ( $\pm 10 \%)$. 
in order to obtain the morphometric index. The method was validated with the original one by Hermann and Stanley [28] with a maximum shift of $\pm 3 \%$.

Geometric Complexity and Information Dimension were automatically calculated using the Benoit 1.3 software, (TruSoft Int'l Inc: http://trusoft-international.com/benoit. html). Algorithmic complexity and Dmin were calculated using a software written by us. All these four methods are routinely performed by one of us in biomedical works [29-33]. Minimum and maximum diameter of the microspherules (Earth and Mars) were automatically measured by the Image Pro Plus software (Media Cybernetics, USA).

\subsection{Statistical Analysis}

Mean intra- and inter-observer coefficients varied $<2.0 \%$
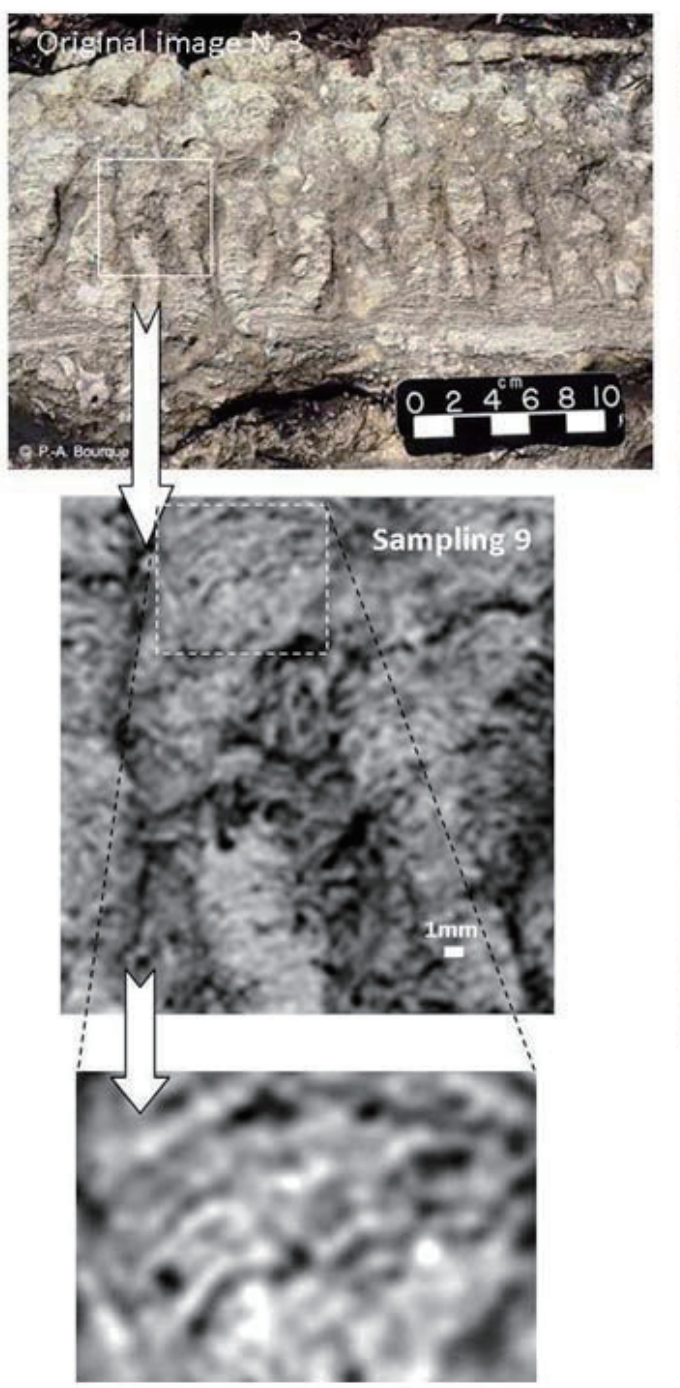

and $<3 \%$, respectively. Comparisons between the groups were analyzed by the Mann-Whitney U test and chi-square test; t-test was applied in order to verify the linearity of the log-log plots.

\section{Results}

\subsection{Earth vs. Mars: visual analysis}

In the visual analysis, amplified image samplings (Table 1, Figs. 5-7), from Earth (stromatolites and other microbialites) as well from Mars (images photographed by Opportunity), reveal:

1) a continuum pattern of microspherules aggregations, dimensions of about $0.1 \mathrm{~mm}-0.3 \mathrm{~mm}$;

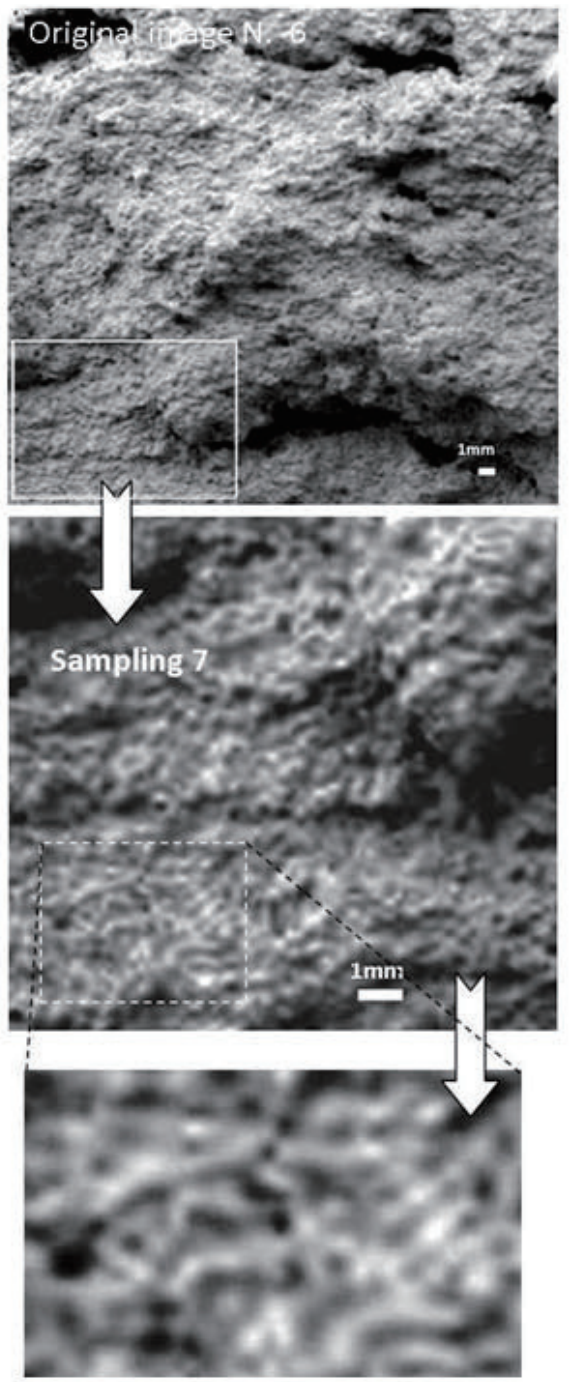

Fig. 5. Earth vs. Mars: A sequence of images from the rover MI imagery (on the right) in comparison with a terrestrial stromatolite (on the left), original images and samplings: see Table 1. Note the similarities of textures made by a mat of microspherules (bottom, right and left) when observed at the same magnification and resolution. 
2) microspherules aggregations in elongated linear settings (intertwined, concentric, filaments);

3) a tangle of linear settings separated by large widespread void spaces;

4) microspherules with different grey tonalities;

5) different degrees of intertwined microstructures, from less ordered to very ordered microstructures (aligned side by side).

It is remarkable that such Earth/Mars parallels were found using WEB images as well as microbialites/stromatolites samples (Figs. 5-7; Table 1). On Earth, these reports are prevalently referred to the evaporitic environment, where the microspherule filaments are known as peloids $[7,12,14$, 34-36].

\subsection{Earth vs. Mars: morphometric analysis}

The morphometric analysis reveals that both textures, from microbialites (Earth) and from selected MI images (Mars), present a multifractal aspect, as revealed by the two straight lines in the log-log plot (Fig. 4). Two textures are present: the texture as a whole (200 - 10 pixels, corresponding to $2 \mathrm{~mm}$ -
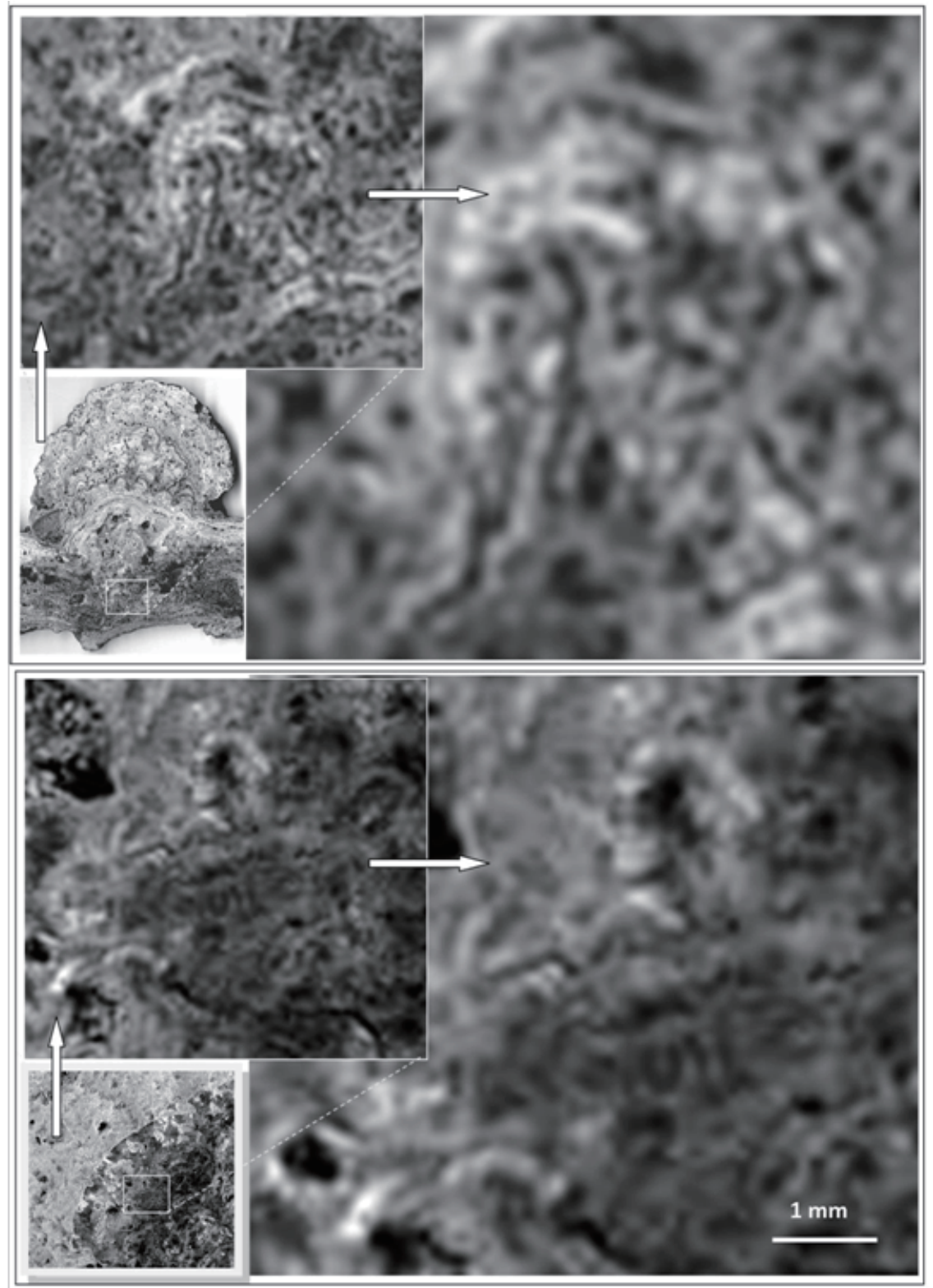

Fig. 6. Earth vs. Mars: Microtextures made by microspherules aggregated in chaotic intertwined filaments (above: a recent stromatolite, Lagoa Salgada, Brazil; below: an image obtained by Opportunity on Mars). Note the remarkable microtextural similarity between them (white bar scale: the same for both). Magnification, resolution and acutance were the same, fixed at the data of the Martian Rover. 
$0.1 \mathrm{~mm}$ ) and the microstructure inside the microspherules and the intertwined filaments of microspherules (10-5 pixels, corresponding to $0.1 \mathrm{~mm}-0.05 \mathrm{~mm}$ ).

The morphometric analysis also shows that the Martian and terrestrial textures were extremely similar to each other; the average values and confidence intervals of the eight independent morphometric parameters of the terrestrial and Martian images perfectly overlapped with each other (Table 2, Fig. 8).

In these eight separate comparisons, the probability of this occurring by chance is $1 / 2^{8}$, less than $\mathrm{p}<.004$.

\subsubsection{Abiogenic pseudostromatolites}

Abiogenic pseudostromatolites (speleothems and synthetic ones) showed changing morphometric indexes according to their origins, having in common a less ordered pattern (higher Lempel-Ziv index), higher geometric complexity, entropy, and tortuosity than those of the terrestrial biogenic stromatolite images or Martian images $(\mathrm{p}<0.001, \mathrm{p}<0.01, \mathrm{p}<0.01, \mathrm{p}<0.01)$ (Table 3).

Abiogenic pseudostromatolites presented a simple fractal structure (at every tested length scale, the microstructure repeats itself perfectly, as indicated by the single linear loglog plot; Figs. 9 and 10).

\section{Discussion}

The search of life on Mars, in the present or in the past history of the planet, is the main motivation behind the research programs since the 'seventies' on the Martian surface. The first images highlighting the evidence for past liquid water on Mars were carried out by orbital images from Mariner 9 [37]. Then, Mars Observer Camera [38] and Mars Reconnaissance Orbiter [39] provided new images of past
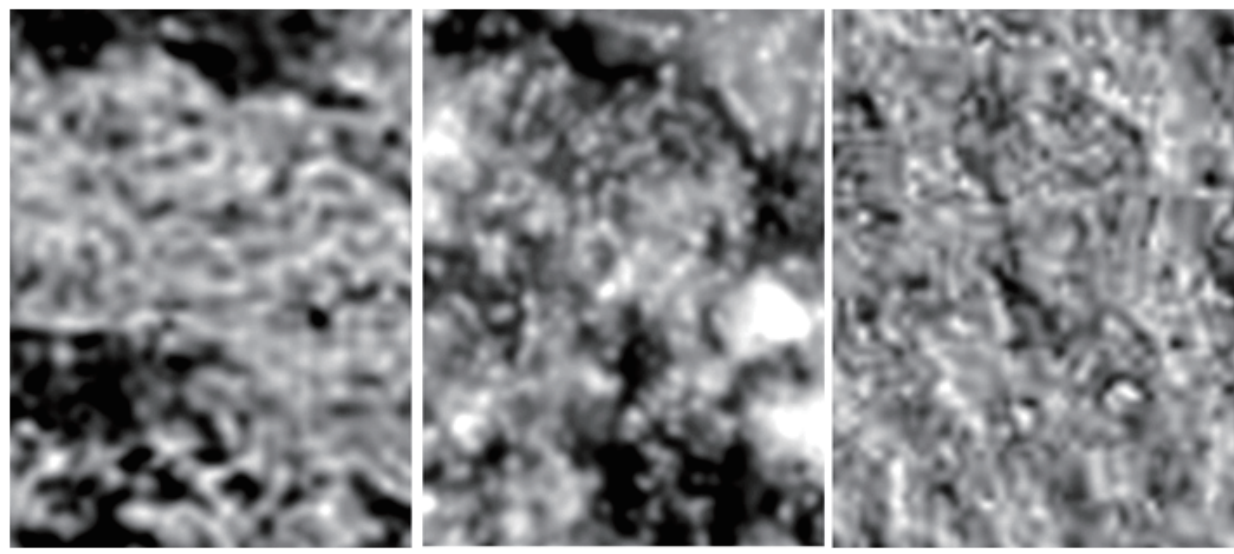

Fig. 7. Earth vs. Mars: Images of a fossil stromatolite (left), of a living microbialite (center) and of a Martian laminated sediment (right), at the same magnification and resolution. Microspherules assembled in filament arrays are present in every image. Magnification, resolution and acutance were the same, fixed at the data of the Martian Rover.

Table 2. Earth vs. Mars, morphometry: Eight different morphometric indexes of microspherule/intertwined filaments of microspherules were obtained from 45 terrestrial microbialite images and 30 Martian images, corresponding to approximately 25,000/15,000 microstructures analyzed. Mean values (standard deviation). Note the remarkable similarity of the Earth/Mars indexes: the probability of this occurring by chance is $1 / 2^{8}$, less than $p<0.004$.

EARTH/ Mean (SD) MARS/ Mean (SD)

\begin{tabular}{|l|l|l|}
\hline Geometric Complexity, High scale & $1.817(0.023)$ & $1.812(0.018)$ \\
\hline Geometric Complexity, Low scale & $1.483(0.070)$ & $1.478(0.071)$ \\
\hline Information Entropy, High scale & $1.876(0.012)$ & $1.874(0.006)$ \\
\hline Information Entropy, Low scale & $1.421(0.050)$ & $1.436(0.046)$ \\
\hline Randomness (Lempel-Ziv index) & $0.458(0.045)$ & $0.468(0.042)$ \\
\hline Tortuosity (Dmin) & $0.777(0.01)$ & $0.775(0.01)$ \\
\hline
\end{tabular}

\begin{tabular}{|l|l|l|}
\hline Minimum diameter $(\mathrm{mm})$ & $0.077(0.002)$ & $0.078(0.002)$ \\
\hline Maximum diameter $(\mathrm{mm})$ & $0.2066(0.003)$ & $0.2068(0.003)$ \\
\hline
\end{tabular}


Table 3. Abiogenic stromatolites vs. Biogenic stromatolites and Martian samples: Nonlinear values are statistically different in the abiogenic (pseudo)stromatolites in comparison to the biogenic stromatolites or Martian samples. Mean values (standard deviation).

Biogenic stromatolites Martian samples Pseudostromatolites

\begin{tabular}{|l|l|l|l|}
\hline Lempel-Ziv index & $0.458(0.045)$ & $0.468(0.042)$ & $0.670(0.13)^{* * *}$ \\
\hline $\begin{array}{l}\text { Geometric complexity, } \\
\text { high and low scales }\end{array}$ & $1.82(0.02) / 1.48(0.07)$ & $1.81(0.02) / 1.48(0.07)$ & $1.90(0.03) * *$ \\
\hline $\begin{array}{l}\text { Entropy, } \\
\text { high and low scales }\end{array}$ & $1.88(0.01) / 1.42(0.05)$ & $1.87(0.01) / 1.44(0.05)$ & $1.92(0.03)^{* *}$ \\
\hline Tortuosity & $0.78(0.01)$ & $0.77(0.01)$ & $0.84(0.06)^{* *}$ \\
\hline $\mathrm{P}$ & & n.s. & $* * * \mathrm{p}<0.001, * * \mathrm{p}<0.01$ \\
\hline
\end{tabular}

fluvial networks on its surface, present a long time ago. Our knowledge on Mars has increased remarkably after the last NASA missions, especially those called Mars Exploration Rover (MER, Opportunity and Spirit rovers) which have been held since 2004 and still ongoing on the Mars landscape. Indeed, photographs realized by the Martian Rovers confirmed the presence of water deposits on the surface of Mars [1,24].

The presence of water is a prerequisite for the search for life, but, of course, it does not prove the presence of life itself. The search on Mars of extraterrestrial microorganisms and, in particular, of cyanobacteria, the main building materials of terrestrial stromatolites and other microbialites, has been suggested by many Authors beginning from the famous discovery of the Martian meteorite, ALH84001 [40]. This biological approach was further suggested by some intriguing images of the Martian surface photographed by the Rover Opportunity, showing a set of rocks partially covered by a dark shiny patina, close to the terrestrial "Desert Varnish" probably formed, suggested some Authors, "by the same bacteria that built stromatolites on Earth" [41].

A century of research on stromatolites and other microbialites has revealed diverse fabrics and many structures together with a contentious history and various definitions [9]. In a general view, stromatolites are the

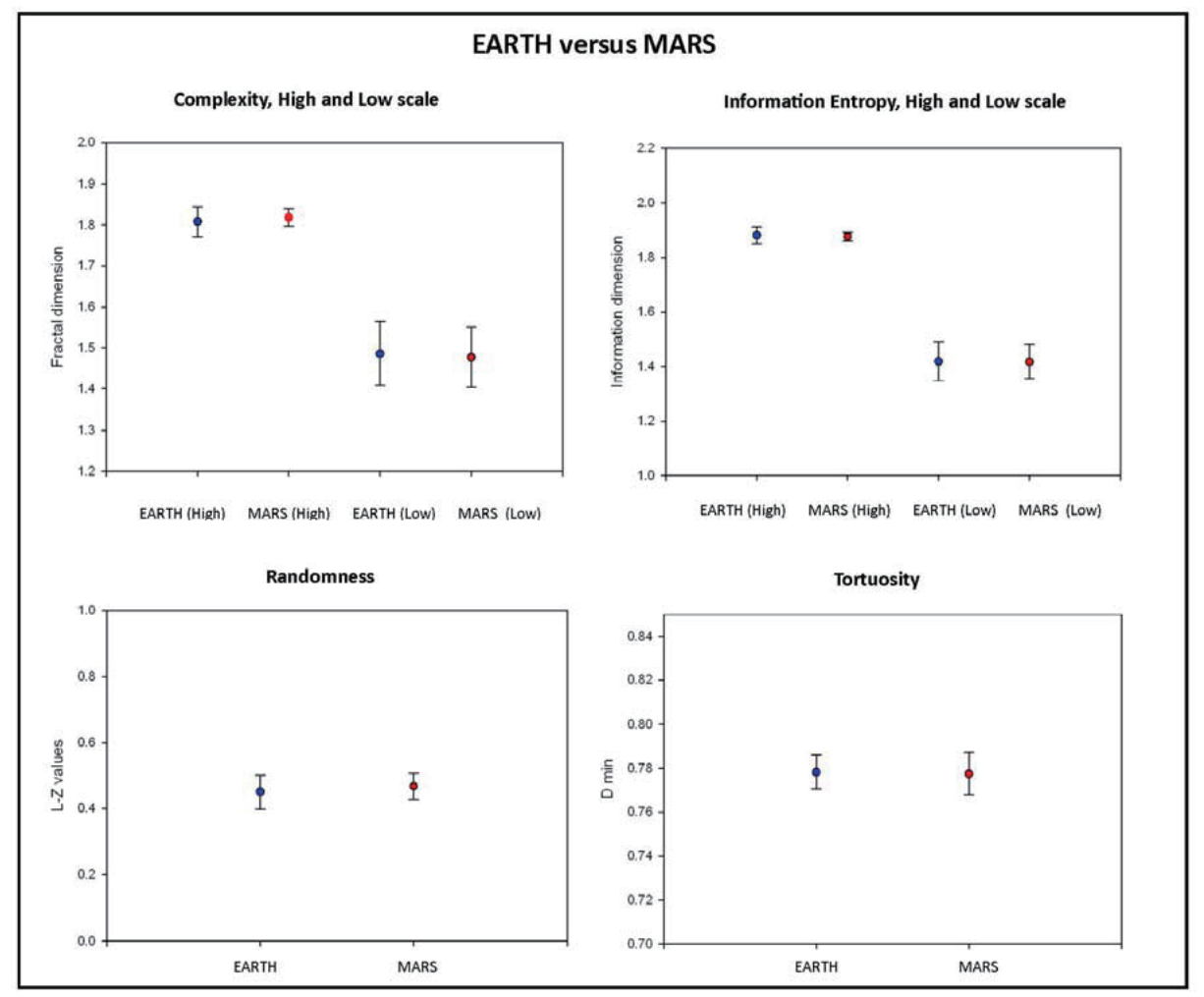

Fig. 8. Earth vs. Mars morphometry: Texture indexes obtained from terrestrial microbialites (Earth) and from Martian images (Mars). Forty-five terrestrial microbialite images and thirty Martian images, approximately corresponding to 25,000/15,000 microstructures analyzed. Note the remarkable similarity of the obtained indexes (Earth/Mars). 
result of a dynamic balance between sedimentation and intermittent lithification of cyanobacterial mats. They could be seen as the result of four main genetic components: biological-non skeletal; biological-skeletal; mechanical clastic and chemical [5, 42]. When stromatolites grow without the aid of sedimentation and in quite waters, they essentially become microlaminated and flat, as a biovarvite [43], in a condition that we could also expect in the last surficial deposits on Mars. Most of microbialites and stromatolites are carbonate in composition, but siliceous, phosphatic, iron, manganese, and sulphate examples also occur [9]. In this frame, the outcroppings on Mars surface at Meridiani Planum subjected to moderate-low diagenesis, the sulphate laminated sediments intercalated somewhere by clay containing a little amount of carbonate and hematite nodules [44], represent an interesting field for microstructure/textures investigations.

In this paper, a tangle of microspherule and intertwined filaments (Table 1, samplings, textures shown on Figs. 1-3, 5-7) has been evidenced on the Martian sediments (also described in an our previous work [21]:) a textural pattern that is also present in living microbialites as well in recent and fossil stromatolites [12-14, 45, 46] (Figs. 5-7). In effect, the tendency of microspherules (as oolites and peloids) to aggregate in more complex arrays was proved as a characteristic of microbial community of cyanobacteria, both in laboratory [45], as well in the field [36, 46].

Note that these peculiar microtextures made by

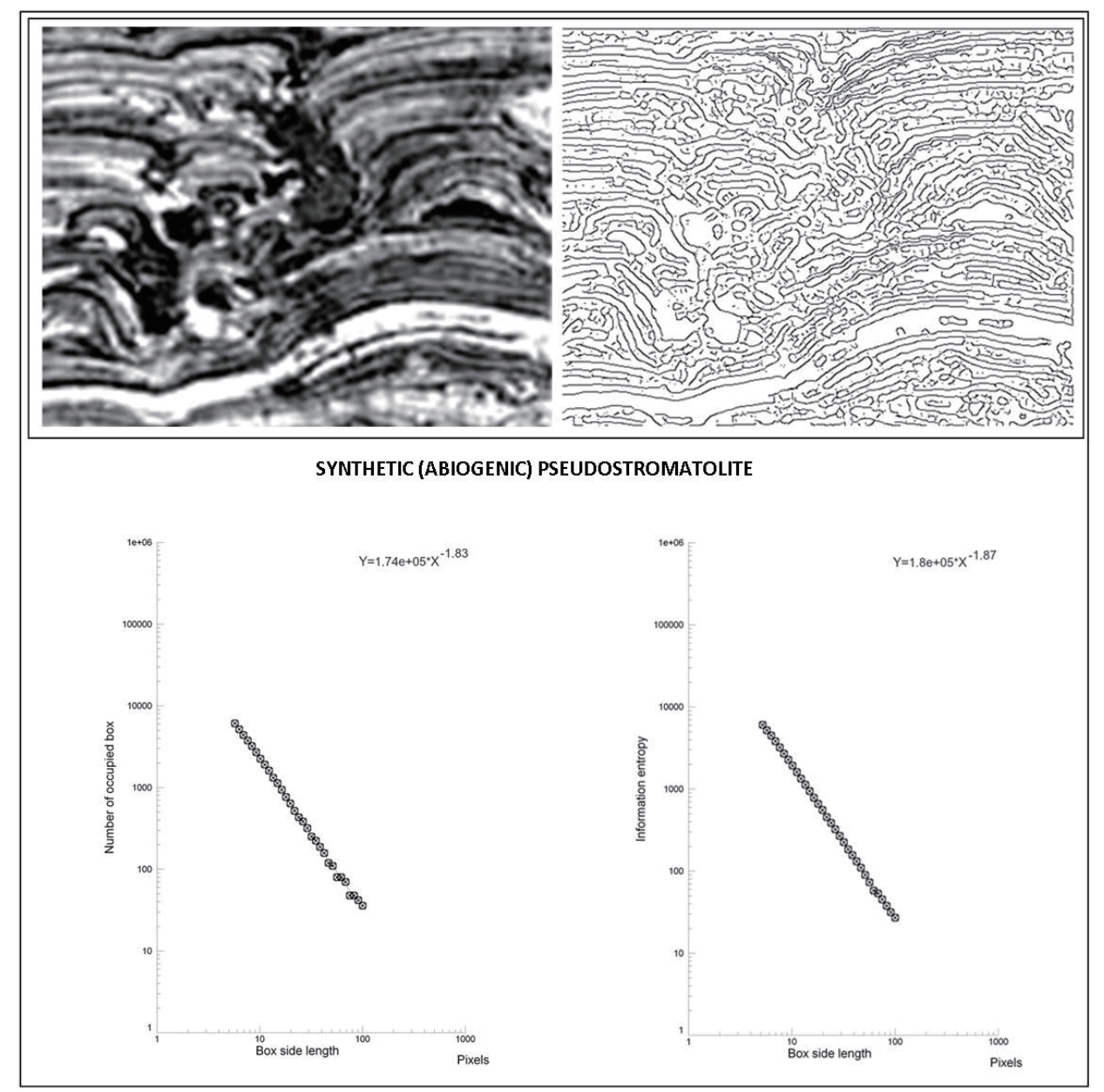

Fig. 9. Earth: synthetic stromatolite: A terrestrial synthetic (abiogenic) pseudostromatolite (top, left, sample from McLoughlin et al.,2008*), its automatically extracted contours (top, right), its log-log plots (bottom). The characteristic fabric made of microspherules and interwined structures present in biogenic stromatolites (Figs. 6, 7), is not present. Morphometric parameters: D0 =1.83, D1=1.87, $\mathrm{L}-\mathrm{Z}=0.573$, Dmin $=0.911$; the log-log plots are fractals (at different length scales, the microstructure repeats itself perfectly for every tested scale [200-5 pixels $=2 \mathrm{~mm}-0.05 \mathrm{~mm}]$ ) but not multifractals like as the biogenic stromatolites or Martian images (Fig. 4). The image was processed like as the biogenic stromatolites and Martian samples; magnification, also, was the same $( \pm 10 \%)$.

*McLoughlin, N., Wilson, L.A., Brasier, M.D., 2008. Growth of synthetic stromatolites and wrinkle structures in the absence of microbes - implications for the early fossil record. Geobiology 6, 95-105. 
microspherule and intertwined filaments are not widespread and not equally distributed on the Martian and terrestrial samples. They take place especially where lamination gives origin to disordered and thrombolytic structures; we had to search for them and we found both on stromatolites, but not everywhere. For example, on samplings of Lagoa Salgada (Table 1, Fig. 6), they are distributed in the lower part of the sample, not everywhere; vice versa, they largely occur in the La Brava living microbialite (Fig. 2), where there is not any lamination.

As regards the scale of the structures analyzed here, we have to note that the metrical range we used for this work is at the limit of visible field, between meso- and micro- structures: a level that is optimal for automatic and mathematical approaches, where point of view or light condition less influences the images.

In this paper, morphometric and objective analysis (measuring geometric complexity, algorithmic complexity, entropy and tortuosity of the microtextures, and the minimum and maximum diameters of the microspherules) shows that the texture indexes and diameter values present in the samples of biogenic stromatolites and other microbialites, fossil and living samples, are extremely similar to those present in MI images taken by the Mars Rover Opportunity. Average values and confidence intervals of the eight independent fractal parameters between Earth (stromatolites and other microbialites) and Mars samples perfectly overlap with each other. The probability of this occurring by chance is $1 / 2^{8}$ (less than $\mathrm{p}<.004$ ). Fractal analysis also reveals that the textures, from microbialite images (Earth) and from the analyzed MI images (Mars), are multifractals, as shown by the two straight lines present in the log-log plots (Fig. 4).

Moreover, the peculiar microfabric present in the (biogenic) stromatolites or other microbialites has not been found in samples of abiogenic (pseudo)stromatolites

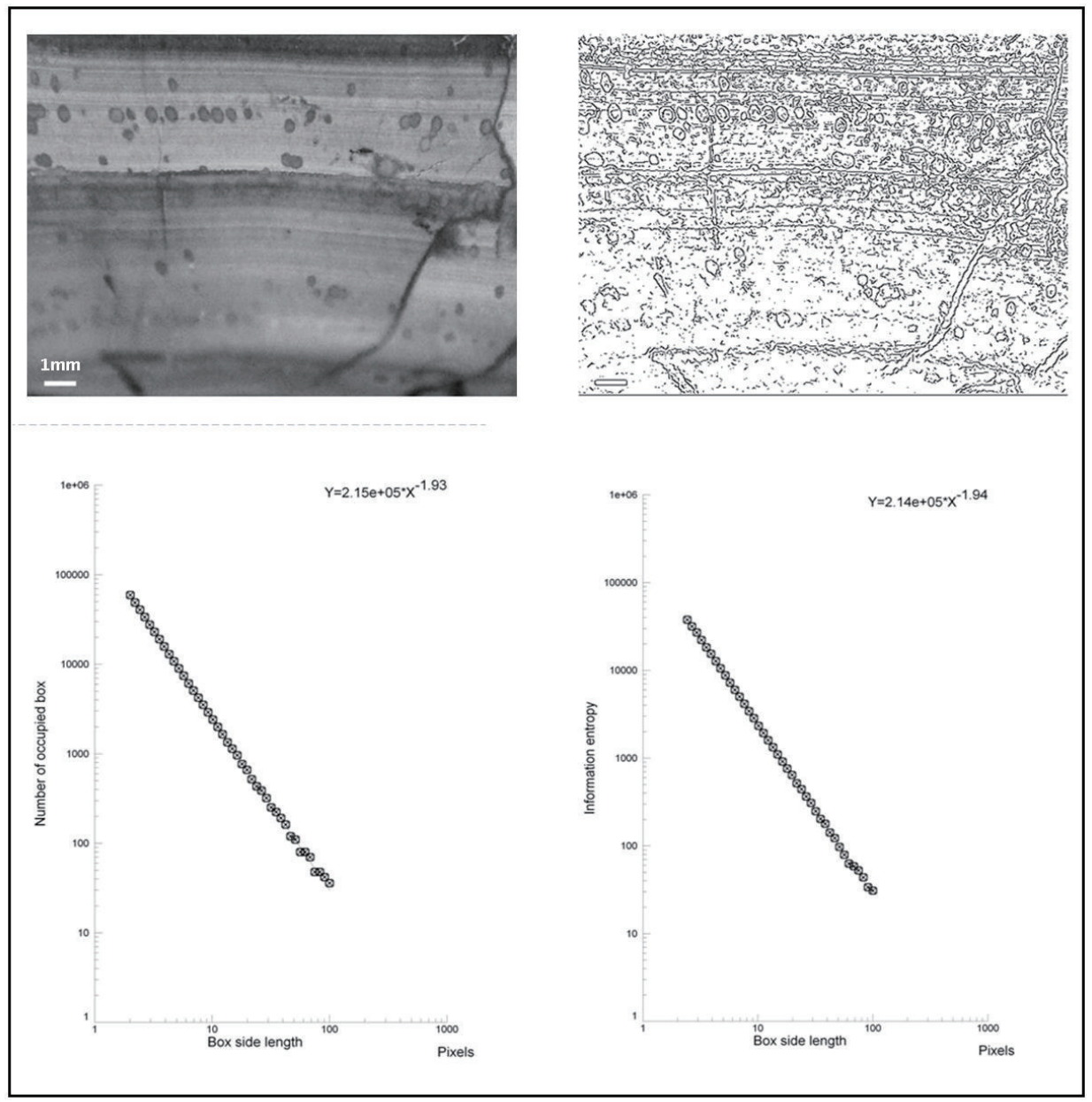

Fig. 10. Earth: abiogenic stromatolite : A speleothem (an abiogenic stromatolite: laminated malachite), its contours and its log-log plots. The characteristic fabric made of microspherules and interwined structures, present in biogenic stromatolites (Figs. 6,7), is not present. Fractal parameters: $\mathrm{D} 0=1.93, \mathrm{D} 1=1.94, \mathrm{LZ}=0.602$, Dmin $=0.724$; the log-log plots are fractals but not multifractals (compare with Fig. 4). The image was processed as the biogenic stromatolites and Martian samples; the scale, also, was the same. 
(speleothems and synthetic pseudostromatolites); they have a simple fractal structure and present a less ordered microstructure than that of the terrestrial microbialites or Martian samples ( $\mathrm{p}<0.001$, Table 3$)$. In effect, even if using different approaches, Grotzinger and Rothmann [47] clearly showed that the existence of a simple fractal structure reveals the abiogenic origin of a (pseudo)stromatolite.

Wagstaff and Corsetti [23] didn't find any identification of the Martian images collected by Opportunity Rover with terrestrial biogenic stromatolites. Differences from our work may be simply explained by the small number of Martian samples analyzed by the Authors (four!) and- first of all - by a quite different scale of observation. The qualification of "stromatolites" based on micro- and meso-scales, as in our work, is more significant than the one based on macroscales as used by Wagstaff and Corsetti, the latter one being more changing and more influenced by the local physical environment.

\section{Conclusions}

In this work, we performed a morphometric approach to evidence the morphological biomarkers in microbialites in order to search for the same indexes in the images collected by the "Opportunity" Martian rover. Morphology is a valid criterion to indicate biogenicity of a stromatolite [48], though none, including morphology, carbon isotopic composition, carbonaceous makeup, other indexes, has been proven as undisputed indicator of biogenicity, if considered alone $[49,50]$. The existence of abiogenic structures that mimic the microbial morphologies of the stromatolites is also well known [51], but the presumptive evidence of microbialites on Mars may be stated here by the striking similarity of each morphometric index we have obtained by analyzing both the terrestrial and Martian images, also supported by statistical analysis $(\mathrm{p}<.004$, overlapping would not happen due to chance).

In conclusion, our results demonstrate the presumptive evidence of biogenic microbialites/stromatolites in the Martian outcroppings, i.e., the presence of unicellular life on the ancient Mars.

\section{Acknowledgement}

We acknowledge the National Aeronautics and Space Administration Mars Exploration Rover Team for their images, which have provided the basis for our study. We thank the Regional Museum of Natural Sciences at Turin, the
Civic Museum of Natural History at Milan, and Prof. Edoardo Perri at University of Calabria, for providing stromatolite samples and pictures. Finally, we would like to thank Prof. Eugenia Maria Farias of CONICET (Argentina) for providing living stromatolite pictures.

\section{References}

[1] Squyres, S.W., Arvidson, R.E., Bell, J.F., Calef , F., Clark, B.C., Cohen, B.A., Crumpler, L.A., De Souza, P.A., Farrand, W.H., Gellert, R., Grant, J., Herkenoff, K.E., Hurowitz, J.A., Johnson, J.R., Jolliff, B.L., Knoll, A.H., Li, A.H., Mclennan, S.M., Ming, D.W., Mittlefehhldt, D.W., Parker, T.J., Paulsen, G., Rice, M.S., Ruff, S.W., Schröder, C., Yen, A.S. and Zacny, K., "Ancient impact and aqueous processes at Endavour Crater, Mars", Science, Vol. 336, 2012, pp. 570-576.

DOI: $10.1126 /$ science. 1220476

[2] Grotzinger, J.P. and Knoll, A.H., "Stromatolites in Precambrian carbonates: evolutionary mileposts or environmental dipsticks?", Annual Reviews Earth Planetary Science, Vol. 27, 1999, pp. 313-358.

[3] Lowe, D.R., "Stromatolites 3.400 - Myr old from the Archean of Western Australia", Nature, Vol. 284, 1980, pp. 441-443.

[4] Hofmann, H.J., Grey, K., Hickman, A.H. and Thorpe, R.I., "Origin of $3.45 \mathrm{Ga}$ coniform stromatolites in Warrawoona Group, Western Australia”, Geological Society of American Bulletin, Vol. 111, 1999, pp. 1256-1262.

[5] Hofmann, H.J., Archean stromatolites as microbial archives, In: Microbial Sediments, pp. 315-327, SpringerVerlag International Publisher Science, Amsterdam, The Netherlands, 2000.

[6] Allwood, A.C., Walter, R.C., Kamber, B.S., Marshal, C.P. and Burch, I.W., "Stromatolite reef from the Early Archean era of Australia", Nature, Vol. 414, 2006, pp. 714-718.

[7] Walter, R.W., Stromatolites, In: Development in sedimentology, 20, Elseiver Scientific Publishing Company, Amsterdam, The Netherlands, 1976.

[8] Aitken, J.D., "Classification and environmental significance of cryptalgal limestones and dolomites, with illustrations from the Cambrian and Ordovician of southwestern Alberta", Journal of Sedimentary Petrology, Vol. 37, 1967, pp. 1163-1178.

[9] Riding, R., The nature of Stromatolites: 3,500 Million years of History and a Century of Research, In: Advances in Stromatolite Geobiology, Lecture Notes in Earth Sciences, Vol. 131, pp. 29-74, 2011

[10] Riding, R., "Abiogenic, microbial and hybrid authigenic carbonate crusts: components of Precambrian 
stromatolites", Geologica Croatica, Vol. 61, No. 2-3, 2008, pp. 73-103.

[11] Grotzinger, J.P., "Cyclicity and paleoenvironmental dynamics, Rocknest platform, Northwest Canada", Geological Society of America Bulletin, Vol. 97, 1986, pp. 1208-1231.

[12] Riding, R., "Microbial carbonates: the geological record of calcified bacterial-algal mats and biofilms", Sedimentology, Vol. 47, Suppl. 1, 2000, pp. 179-214.

[13] Allwood, A.C., Burch, I.W., Rouchy, J.M. and Coleman, M., "Morphological Biosignatures in Gypsum: Diverse Formation Processes of Messinian (6.0 Ma) Gypsum Stromatolites", Astrobiology, Vol. 13, No.9, 2013, pp. 870-886.

DOI: 10.1089/ast.2013.1021

[14] Riding, R., Microbial carbonates: processes and products in time and space, In: 17th International Sedimentological Congress, Fukuoka, Japan, Abstracts, Vol. A, No. 12, 2006.

[15] McKay, C.P. and Stoker, C.R., "The early environment and its evolution on Mars: implications for life", Reviews of Geophysics, Vol. 27, No. 2, 1989, pp. 189-214.

[16] Walter, M.R. and Des Marais, D.J., "Preservation of biological information in thermal spring deposits developing a strategy for the search for fossil life on Mars", Icarus, Vol. 101, 1993, pp. 129-143.

[17] Ellery, A., Wynn-Williams, D.D., Parnell, J., Edwards, H.G.M. and Dickensheets, D.L., "The role of Raman spectroscopy as an astrobiological tool in the exploration of Mars", Journal of Raman Spectroscopy, Vol. 35, 2004, pp. 441457.

[18] McKay, C.P., "Wet and cold thick atmosphere on early Mars", Journal de Physique France, Vol. 121, 2004, pp. 283288.

[19] Jepsen, S.M., Priscu, J.C., Grimm, R.E. and Bullock, M.A., "The potential for Lithoautotrophic life on Mars: application to shallow interfacial Water Environments", Astrobiology, Vol. 7. No.2, 2007, pp. 342-354.

[20] Clarke, J.D. and Stocker, C.R., "Searching for stromatolites: the 3.4 ga Strelley Pool Formation (Pilbara region, Western Australia) as a Mars analogue", Icarus, Vol. 224, 2013, pp. 413-423.

[21] Rizzo, V. and Cantasano, N., "Possibile organosedimentary structures on Mars", International Journal of Astrobiology, Vol. 8, No. 4, 2009, pp. 267-280.

[22] Rizzo, V. and Cantasano, N., "Textures on Mars: evidences of a biogenic environment", Memorie della Società Astronomica Italiana, Vol. 82, No. 2, 2011, pp. 348-357.

[23] Wagstaff, K.L. and Corsetti, F.A., "An evaluation of information-theoretic methods for detecting structural microbial biosignatures", Astrobiology, Vol. 10, No. 4, 2010, pp. 363-379.
DOI: 10.1089/ast.2008.0301.

[24] Squyres, S.W., Grotzinger, J., Arvidson, R.E., Bell, J.F., Calvin, W., Christensen, P.R., Clark, B.C., Crisp, J.A., Farrand, W., Herkenhoff, K.E., Johnson, J.R., Klingelhöfer, G., Knoll, A.H., McLennan, S.M., McSween, H.Y., Morris, R.V., Rice Jr., J.W., Rieder, L. and Soderblom, L.A., "In Situ Evidence for an Ancient Aqueous Environment at Meridian Planum, Mars", Science, Vol. 36, No. 5702, 2004, pp. 1709-1714.

[25] Falkoner, K., Fractal Geometry. Mathematical Foundations and Applications, John Wiley \& Sons Ltd., 1990.

[26] Pitsianis, N., Bleris, G.L. and Argyrakis, P., "Information dimension in fractal structures", Physical Review B, Vol. 39, No. 10, 1989, pp. 7097-7100.

[27] Kaspar, F. and Schuster, H.G., "Easily calculable measure for the complexity of spatiotemporal patterns", Physical Review A, Vol. 36, 1987, pp. 842-848.

[28] Hermann J. and Stanley H.E., "The fractal dimension of the minimum path in two and three dimensional percolation", Journal of Physics A, Vol. 21, 1988, pp. 829-833.

[29] Bianciardi, G., Miracco, C., De Santi, M.M. and Luzi, P., "Differential diagnosis between mycosis fungoides and chronic dermatitis by fractal analysis", Journal of Dermatological Sciences, Vol. 33, 2003, pp. 184-186.

[30] Bianciardi, G., Tanganelli, I., Totangiancaspro, D., Brogi, M., Carducci, A. and De Santi, M.M., "Fractal Analysis of monocytes in Diabetes", Clinical Hemorheology and Microcirculation, Vol. 35, No. 1-2, 2006, pp. 269- 272.

[31] Bianciardi, G., Traversi, C., Cattaneo, R., De Felice, C., Monaco, A., Tosi, G., Parrini, S. and Latini, G., "Phase transition of the Microvascular Network. Architecture in Human Pathologies", Theoretical Biology Forum, Vol. 105, No. 1, 2012, pp. 37- 45.

[32] Bianciardi, G., Miracco, C., Lazzi, S. and Luzi, P., "Fractal analysis of Epithelial-Connective Tissue in Basal Cell Carcinoma of the skin", Current Bioinformatics, Vol. 8, 2013, pp. 357-361.

[33] Bianciardi, G., Acampa, M., Lamberti, I., Sartini, S., Servi, M., Biagi, F., Bocchi, V., Hayek, J. and Pastorelli, M., "Microvascular abnormalities in Rett syndrome", Clinical Hemorheology and Microcirculation, Vol. 54, 2013, pp. 109113.

\section{DOI: $10.3233 / \mathrm{CH}-131707$}

[34] Folk, R.L., Petrology of Sedimentary Rocks, Hemphill Publishing Company, Austin, Texas, 1980.

[35] Chafetz, H.S., "Marine peloids: A product of bacterially induced precipitation of calcite", Journal of Sedimentary Petrology, Vol. 56, 1986, pp. 812-817.

[36] Reid, R.P., Vissker, P.T., Decho, A., Stolz, J.K., Bebout, B.M.,Dupraz, C., Macintyre, I.G., Paerl, H.W., Pinchney, J.L., Prufert-Bebout, L., Steppe, T.F. and Des Marais, D.J., “The role 
of microbes in accretion, lamination and early lithification of modern marine stromatolites", Nature, Vol. 406, 2000, pp. 989-992.

[37] Carr, M.H., The surface of Mars, Yale University Press, New Haven, 1981.

[38] Malin, M.C. and Carr, M.H., "Groundwater formation on Martian valleys", Nature, Vol. 397, 1999, pp. 589-591.

[39] McEwen, A.S., Hansen, C.J., Delamere, W.A., Eliason, E.M., Herkenhoff, K.E., Keszthelyi, L., Gulick, V.C., Kirk, R.L., Mellon, M.T., Grant, J.A., Thomas, N., Weitz, C.M.,Squyres, S.W., Bridges, N.T., Murchie, S.L., Seelos, F., Seelos, K., Okubo, C.H., Milazzo, M.P., Tornabene, L.L., Jaeger, W.L., Byrne, S., Russel, P.S., Griffes, J.L., Martinez-Alonso, S., Davatzes, A., Chuang, F.C., Thomson, B.J., Fishbaugh, K.E., Dundas, C.M., Kolb, K.J., Banks, M.E. and Wray, J.J., "A closer look at waterrelated geologic activity on Mars", Science, Vol. 317, 2007, pp. 1706-1709.

[40] McKay, D.S., Gibson Jr., E. K. and Thomas-Keprta, K.L., Vali, H., Romanek, C.S., Clemett, S.J., Chillier, D.F., Maechling, C.R., Zare, R.N., "Search for past life on Mars: Possible Relic Biogenic Activity in Martian Meteorite ALH84001", Science, Vol. 273, 1996, pp. 924-930.

[41] Di Gregorio, B.E., "Martian sheen: life on the rocks", New Scientists, Vol. 2747, 2010, pp. 40-43.

[42] Hofmann, H.J., "Stromatolites: characteristics and utility”, Earth Science Review, Vol. 9, 1973, pp. 339-373.

[43] Gerdes, G., Structures left by modern microbial mats in their host sediments, in: Atlas of microbial mat features within the clastic rock record, Elseiver Scientific Publishing Company, Amsterdam, The Netherlands, 2007.
[44] Grotzinger, J.P., Beaty, D., Dromart, G., Gupta, S., Harris M., Hurowitz, J., Kocurek, G., McLennann, S., Milliken, R., Ori, G.G. and Suner, D., "Mars sedimentary Geology: Key concepts and outstanding questions", Astrobiology, Vol. 11. No. 1, pp. 2011, pp. 77-87.

[45] Brehm, U., Palinska, K.A. and Krumbein, W.E., "Laboratory cultures of calcifying biomicrospheres generate oids. A contribution to the origin of oolites", Notebooks on Geology, Maintenon Letters, No. 03, 2004, CG2004-L03.

[46] Reid, R.P., James, N.P., Macintyre, I.G., Dupraz, C.P. and Burne, R.V., "Shark Bay stromatolites: Microfabrics and reinterpretation of origins", Facies, Vol. 49, 2003, pp. 45-53.

[47] Grotzinger, J.P. and Rothman, D.H., "An abiotic model for stromatolite morhogenesis", Nature, Vol. 383, 1996, pp. 423-425.

[48] Awramik, S.M. and Gray, K., Stromatolites: Biogenicity, biosignatures and bioconfusion, in: Proceedings of SPIE, No. 5906, 2005, pp. 1-9.

[49] Schopf, J.W., Kudryavtsev, A.B., Czaja A.D. and Tripathi, A.D., "Evidences of Archean life: Stromatolites and microfossils", Precambrian Research, Vol. 158, 2007, pp. 141155.

[50] Purdon, G. and Snelling, A., "Survey of Microbial Composition and Mechanisms of Living Stromatolites of the Bahamas and Australia: Developing Criteria to Determine the Biogenicity of Fossil Stromatolites", Answers in Genesis, Vol. 3, 2013, pp. 348-350.

[51] Bosak, T., Souza-Egipsy, V. and Newman, D.K., "A laboratory model of abiotic peloid formation", Geobiology, Vol. 2, 2004, pp. 189-198. 